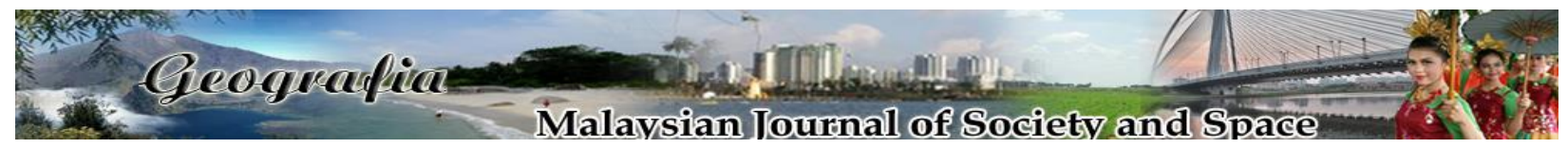

\title{
Persepsi pemegang taruh terhadap sistem perkhidmatan pengangkutan di kampus universiti
}

\author{
Nor Aini Mohamed, Asnarulkhadi Abu Samah, Nurul Akhtar Kamaruddin, Jeffrey Lawrence D’Silva, \\ Hayrol Azril Mohamed Shafril, Dzuhailmi Dahalan \\ Institut Pengajian Sains Sosial, Universiti Putra Malaysia \\ Correspondence: Nor Aini Mohamed (email:nm_aini@upm.edu.my)
}

Received: 20 March 2019; Accepted: 17 April 2019; Published: 14 May 2019

\begin{abstract}
Abstrak
Sistem perkhidmatan pengangkutan merupakan elemen utama dalam sesebuah kampus universiti yang didiami oleh komuniti yang mempunyai ciri yang pelbagai. Komuniti universiti yang terdiri daripada pelajar, staf dan pelawat menjalankan pelbagai aktiviti harian yang menjadikan kampus universiti adalah sebagai satu bandar yang sibuk. Oleh itu, kajian ini bertujuan untuk mengenal pasti keberkesanan sistem perkhidmatan pengangkutan berdasarkan persepsi pemegang taruh di Universiti Putra Malaysia, Serdang. Kajian kuantitatif ini menggunakan borang soal selidik melibatkan 1,373 orang responden yang terdiri daripada pelajar (prasiswazah dan siswazah), staf (akademik, pengurusan dan profesional, pelaksana) dan pelawat dengan menggunakan teknik persampelan rawak mudah. Analisis data kajian adalah secara deskriptif. Hasil kajian menunjukkan pemegang taruh mempunyai persepsi yang positif terhadap item bagi domain operasi pintu pagar, parkir, dan perkhidmatan bas berdasarkan nilai skor min yang tinggi. Manakala, item bagi domain papan tanda arah, aliran trafik, dan sikap pengguna menunjukkan nilai skor yang sederhana. Kesimpulannya, responden berpuas hati dengan sistem perkhidmatan pengangkutan, namun penambahbaikan masih perlu dilaksanakan selaras dengan misi dan matlamat universiti. Implikasinya, sesebuah kampus universiti yang lestari memerlukan sistem perkhidmatan pengangkutan di kampus yang cekap dan tidak menjejaskan alam sekitar dengan menggalakkan aktiviti berbasikal dan berjalan kaki. Hal ini akan memberi kesan positif kepada pencapaian universiti secara keseluruhan dan menghasilkan komuniti universiti yang produktif.
\end{abstract}

Kata kunci: komuniti universiti, parkir, pemegang taruh, persekitaran kampus, sikap pengguna, sistem perkhidmatan pengangkutan 


\title{
Stakeholder perceptions towards transportation service system in university campus
}

\begin{abstract}
The transportation services system is a major element in a university campus populated by a diverse community of people. The university community consists of students, staff, and visitors who conduct day-to-day activities that make the university campus a busy city. Thus, this research aims to evaluate the effectiveness of the transportation service system based on the perceptions of stakeholders in Universiti Putra Malaysia, Serdang. The quantitative study used a questionnaire survey on 1,373 respondents comprising of students (undergraduate and postgraduate), staff (academic, professional and management, implementers) and visitors. The random sampling method was used for the study. The results are analysed descriptively. The result of the study shows that the respondents gave positive perceptions to items on gate operations domain, parking domain, and bus services based on the high mean scores. However, items under the signboard domain, traffic flow domain and users attitude domain shows moderate mean score. As a conclusion, the respondents are satisfied with the provided transportation service system but improvements are needed in line with the university's mission and aims. The implication of this study shows that a sustainable university campus requires an efficient on-campus transportation service system that does not affect the environment by promoting cycling and walking activities among its students and staffs. This will have a positive impact on the achievement of the university as a whole and produce a productive university community.
\end{abstract}

Keywords: campus university, parking, stakeholders, transportation service system, university community, users attitude.

\section{Pengenalan}

Sesebuah universiti yang berusaha mencapai kelestarian perlu berhadapan dengan isu pengangkutan. Kampus universiti didiami oleh satu komuniti yang memiliki ciri yang pelbagai. Pelajar dan staf yang berbeza dari segi latar belakang, pendapatan, cara hidup serta sikap berkumpul untuk belajar dan bekerja di dalam kampus universiti (Balsas, 2003). Pergerakan masuk dan keluar kampus menggambarkan bahawa sesebuah kampus universiti memberi kesan terhadap masyarakat dan persekitaran (Miralles \& Domene, 2010). Oleh itu, kampus universiti semakin berkembang menjadi sebuah kawasan yang kompleks bagaikan sebuah kawasan bandar. Tambahan pula, projek pembangunan yang dilaksanakan berdekatan kampus seperti projek perumahan dan pembangunan infrastruktur secara tidak langsung menambah kepadatan penduduk dan bilangan kenderaan. Kampus Universiti Putra Malaysia (UPM) yang terletak di Serdang, Selangor juga tidak terkecuali menghadapi cabaran dalam menyelesaikan isu ini.

Sebagai sebuah institusi pendidikan yang mempunyai taraf Universiti Penyelidikan (Research University), UPM melaksanakan pelbagai perubahan dalam memastikan agenda sebuah RU dapat dicapai. Ini termasuklah penyediaan kemudahan infrastruktur penyelidikan dan peningkatan pengambilan tenaga kerja, khususnya yang berkaitan dengan penyelidikan dan 
inovasi serta lain-lain prasarana sosial termasuklah kemudahan dan sistem pengangkutan. Hasil kajian Indeks Kegembiraan UPM Fasa 2, 2017 mendapati bahawa staf UPM berasa kurang gembira dengan sistem lalu lintas dan kewujudan laluan basikal (Asnarulkhadi et al., 2018). Kebelakangan ini, terdapat aduan dalam kalangan staf yang mempunyai masalah tiada tempat parkir kenderaan di kampus induk UPM Serdang. Hal ini sedikit sebanyak boleh menjejaskan rasa kegembiraan untuk bekerja dalam kalangan warga kampus.

Oleh itu, satu kajian ke atas kemudahan dan sistem perkhidmatan pengangkutan universiti perlu diusahakan bagi merungkai beberapa masalah yang berkaitan dengannya sebelum mencadangkan pelan tindakan penambahbaikan yang lebih holistik, cekap dan mesra pengguna. Kajian ini bertujuan untuk mengenal pasti keberkesanan sistem perkhidmatan pengangkutan berdasarkan persepsi pemegang taruh di Universiti Putra Malaysia, Serdang. Perkara ini amatlah diperlukan dalam memastikan kegembiraan dapat dikekalkan seterusnya dapat menyumbang dengan lebih produktif kepada pencapaian universiti.

\section{Kajian literatur}

Sesebuah universiti mempunyai jumlah kakitangan akademik yang besar, pelajar dan kakitangan pentadbiran, serta pelbagai aktiviti yang dilaksanakan boleh disamakan dengan sebuah bandar kecil (Mat et al., 2009). Oleh yang demikian, warga kampus dan pelawat luar yang melaksanakan urusan di dalam kampus amat memerlukan satu sistem perkhidmatan pengangkutan yang cekap.

Sejajar dengan perkembangan pendidikan tinggi, universiti akan mengalami pertambahan populasi dan hal ini akan meningkatkan penggunaan kenderaan, seterusnya membawa kepada masalah kekurangan lot parkir kenderaan dan meningkatkan pencemaran (Juarez, 2011). Universiti sebagai kampus korporat menghadapi cabaran dalam memenuhi keperluan lot tempat letak kenderaan dan pada masa yang sama perlu memenuhi keperluan pengangkutan komuniti kampus. Walaupun lot letak kenderaan yang mencukupi dapat membantu dalam interaksi antara pelajar dan kakitangan, tetapi ianya memerlukan kos yang tinggi dan boleh menyebabkan kemusnahan alam sekitar. Oleh yang demikian, sesebuah kampus terutama yang dibina di kawasan bandar perlu mengimbangi kecukupan lot tempat letak kenderaan dengan kekangan tanah dan peningkatan penggunaan kenderaan di dalam kampus (Riggs, 2014). Sehubungan itu, perancang kampus perlu mengambilkira pelbagai faktor untuk memastikan keselesaan kepada semua penghuni kampus. Kebanyakan kampus universiti direka bentuk sebagai kampus pejalan kaki, tetapi dibelenggu dengan budaya yang menggalakkan penggunaan kenderaan. Ini akan memberi lebih tekanan kepada pihak pengurusan untuk membina lebih banyak lot tempat letak kenderaan dan melebarkan jalan. Hal ini akan memberi kesan kepada kemudahan infrastruktur yang lebih mesra alam seterusnya mengurangkan penggunaan kenderaan bermotor (Toor \& Havlick, 2004).

Di Malaysia, beberapa universiti awam dan swasta telah melaksanakan kajian ke atas keberkesanan sistem perkhidmatan pengangkutan di kampus masing-masing. Hasil kajian yang dilaksanakan di Universiti Kebangsaan Malaysia, Bangi mendapati penjadualan perjalanan yang tidak efisien dan ketidakselesaan merupakan masalah utama yang dinyatakan oleh para pelajar dalam menggunakan pengangkutan bas di dalam kampus (Nursyuhadah \& Amirussin, 2011). Perkhidmatan bas dalam kampus yang tidak memuaskan menyebabkan pelajar gagal hadir ke kelas, membazir masa dan tidak menggalakkan pelajar untuk menggunakan perkhidmatan 
tersebut pada masa akan datang. Ketidakselesaan yang dihadapi oleh pelajar dalam menggunakan khidmat pengangkutan yang disediakan oleh universiti boleh memberi persepsi negatif terhadap sistem perkhidmatan itu sendiri (Hashim et al., 2013). Faktor yang mempengaruhi pemilihan penggunaan perkhidmatan bas dalam kampus ialah perkhidmatan di perhentian bas, perkhidmatan bas, dan perkhidmatan oleh pemandu bas (Shaaban \& Kim, 2016). Perhentian bas yang teduh, selamat, bersih, tidak padat akan menarik pengguna untuk menggunakan perkhidmatan yang disediakan, selain bas yang menepati waktu perjalanan dan jarak menunggu yang tidak lama. Sikap pemandu bas dan kepatuhan kepada undang-undang jalan raya juga merupakan penyumbang kepada kepuasan penggunaan bas dalam kampus. Kajian terkini oleh Azani et al. (2017) mendapati sikap pemandu dan sistem perjalanan bas merupakan faktor yang mempengaruhi tahap kepuasan pelajar terhadap perkhidmatan bas di Universiti Utara Malaysia.

Satu kajian komprehensif oleh Roshandeh dan Puan (2009) terhadap sistem pengangkutan di Universiti Teknologi Malaysia, Skudai telah mencadangkan langkah-langkah yang boleh diambil dalam meningkatkan keberkesanan sistem pengangkutan di dalam kampus iaitu (i) perubahan dalam pengurusan lot tempat letak kenderaan dan jalan, (ii) program pengurusan pengangkutan dengan sokongan pihak pengurusan tertinggi universiti, (iii) meningkatkan pilihan pengangkutan alternatif (berjalan kaki dan berbasikal), (iv) perkongsian kenderaan dan penggunaan teksi dan (v) penggunaan teknologi seperti video konferensi.

Pelajar universiti merupakan satu contoh kumpulan sosial yang cenderung untuk mempamerkan tingkah laku pergerakan yang unik dan kompleks. Dalam satu kajian di sebuah universiti awam di Thailand, kebergantungan sosial yang tinggi dalam kalangan pelajar universiti menyebabkan pembangunan model pengangkutan dalam kalangan pelajar universiti menjadi sukar (Limanond et al., 2011). Pemilihan penggunaan pengangkutan dalam kalangan pelajar universiti dipengaruhi oleh faktor situasi (infrastruktur sedia ada, kemudahan transit, ciri dan kos) dan faktor psikologikal (kemahuan individu, kepercayaan, norma dan sifat) (Klöckner \& Friedrichsmeier, 2011). Kos, sikap individu dan persekitaran merupakan faktor yang mempengaruhi pemilihan jenis pengangkutan oleh pelajar (Whalen et al., 2013).

Peratusan pelajar universiti yang menggunakan basikal dan berjalan kaki adalah rendah (Kaplan, 2015). Antara faktor yang mempengaruhi ialah kekangan masa, keadaan cuaca dan faktor keselamatan dalam kampus yang sibuk. Di Malaysia, kebanyakan aktiviti berbasikal dalam kampus adalah untuk tujuan riadah, dan penggunaan basikal untuk ke kuliah adalah masih minima (Harifah et al., 2018). Yuan et al. (2017), mendapati bahawa laluan basikal yang selamat dan parkir basikal merupakan elemen penting untuk meningkatkan penggunaan basikal dalam kalangan pelajar universiti. Ruang parkir basikal boleh ditambahbaik dengan menyediakan perkhidmatan pam tayar, tempat pembaikan kerosakan, kawalan keselamatan, serta kawasan parkir yang bertanda dan sesuai dengan saiz basikal.

Berjalan kaki, berbasikal dan menggunakan pengangkutan awam merupakan bentuk pengangkutan yang aktif kerana melibatkan aktiviti fizikal. Penggunaan pengangkutan awam turut dikatogerikan sebagai pengangkutan aktif kerana di awal atau akhir perjalanan akan turut melibatkan aktiviti berjalan kaki. Zhou et al. (2012) telah menyenaraikan faktor yang mempengaruhi pemilihan pengangkutan dalam kalangan pelajar universiti, iaitu (i) persekitaran dan faktor perbandaran, (ii) faktor spesifik seperti keselesaan, keselamatan, kos perjalanan, (iii) ciri peribadi seperti jantina, umur, pemilikan lesen, (iv) ciri perjalanan seperti masa perjalanan, tujuan, (v) kos parkir, pas parkir dan (vi) psikologikal seperti kesedaran tentang alam sekitar dan sikap. Oleh itu, strategi yang dirancang untuk menggalakkan staf dan pelajar menggunakan mod 
pengangkutan aktif ini berpotensi untuk bukan sahaja mengurangkan permintaan tempat letak kereta dan kesan ke atas persekitaran universiti, malahan juga meningkatkan tahap kesihatan pelajar dan staf. Tambahan pula, kajian ke atas orang dewasa mendapati bahawa peningkatan aktiviti fizikal berpotensi untuk mengurangkan tekanan dan seterusnya meningkatkan pencapaian akademik bagi pelajar (Field et al., 2001). Bagi staf pula,ini akan dapat meningkatkan tahap kegembiraan dan seterusnya dapat menyumbang kepada pencapaian organisasi dengan lebih cemerlang. Selain itu, faedah bentuk pengangkutan aktif termasuklah mengurangkan kesesakan trafik, mengurangkan kadar pencemaran dan juga mengurangkan kesan negatif tekanan akibat kesesakan trafik terhadap kesejahteraan kehidupan (Shannon et al., 2006).

Selain itu, papan tanda arah juga memainkan peranan penting dalam membantu pergerakan pelajar, staf dan pelawat. Papan tanda arah yang menggunakan hanya satu bahasa sahaja iaitu Bahasa Melayu memberi kesulitan kepada pelajar antarabangsa (Mahmud et al., 2010). Kajian oleh Sahrir et al. (2012) mendapati bahawa warna, kontras, mudah dibaca, penyelenggaraan, kedudukan papan tanda, dan papan tanda berbilang bahasa merupakan faktor yang mempengaruhi keberkesanan papan tanda arah.

\section{Metod dan kawasan kajian}

Kajian ini adalah kajian deskriptif menggunakan pendekatan kuantitatif dengan menggunakan borang soal selidik sebagai alat pengukuran. Borang soal selidik dibina berdasarkan kajian literatur dan data temu bual kumpulan berfokus yang dilaksanakan bersama tiga kumpulan informan iaitu (i) staf Bahagian Keselamatan, (ii) pelajar siswazah dan (iii) pelajar prasiswazah. Pengujian 39 item yang mewakili enam domain iaitu papan tanda arah, operasi pintu pagar, aliran trafik, sikap pengguna, parkir dan perkhidmatan bas adalah berbentuk respons tertutup menggunaka skala likert. Skala likert lima mata yang digunakan ialah (1) Sangat tidak setuju, (2) Tidak setuju, (3) Agak setuju, (4) Setuju dan (5) Sangat setuju. Bagi menguji kebolehpercayaan item, kajian rintis telah dilaksanakan dan nilai kebolehpercayaan yang diperolehi ialah sebanyak 78 peratus.

Persampelan rawak mudah digunakan untuk dengan melibatkan 1,373 orang responden yang terdiri daripada pelajar (prasiswazah dan pasca siswazah), staf (akademik dan bukan akademik) dan pelawat dari 15 fakulti di kampus Universiti Putra Malaysia, Serdang, Selangor. Data kajian ini dianalisa menggunakan SPSS dengan pengujian statistik deskriptif. Skala interpretasi yang digunakan bagi skor min dalam kajian ini ialah seperti berikut (Mohd Majid, 2000):

$\begin{array}{ll}\text { 1.0-2.33 } & \text { Tahap Rendah } \\ \text { 2.34-3.67 } & \text { Tahap Sederhana } \\ \text { 3.68-5.00 } & \text { Tahap Tinggi }\end{array}$

\section{Hasil kajian dan perbincangan}

\section{Maklumat demografi}

Jumlah keseluruhan pemegang taruh yang terlibat dalam kajian ini ialah seramai 1,373 orang. Daripada jumlah tersebut, $51.0 \%$ adalah pelajar prasiswazah, $25.1 \%$ adalah pelajar pasca 
siswazah, 21.7\% adalah kakitangan dan selebihnya adalah pelawat agensi luar termasuk kakitangan pos dan kontraktor. Dari segi kaedah pengangkutan untuk bergerak dalam kampus, majoriti responden menggunakan kereta dan motosikal, manakala $34.6 \%$ menggunakan bas. Pengoperasian Grab Car di dalam kampus dilihat sebagai satu alternatif kepada warga kampus untuk bergerak, terutama para pelajar. Kajian mendapati $11.7 \%$ responden menggunakan perkhidmatan ini. Sejumlah kecil iaitu hanya 3.6\% responden menggunakan basikal untuk bergerak dalam kampus. Hasil kajian ini selari dengan dapatan kajian oleh Kaplan (2015) yang mendapati peratusan pelajar yang menggunakan basikal dalam kampus adalah sangat sedikit. Walaupun terdapat pelbagai kemudahan yang disediakan untuk penunggang basikal, namun faktor lain seperti keadaan cuaca dan keselamatan dalam kampus yang sibuk mempengaruhi pelajar dan warga kampus untuk menggunakan basikal.

\section{Persepsi terhadap keberkesanan papan tanda arah}

Secara keseluruhannya, semua item berkenaan papan tanda menunjukkan nilai min pada tahap sederhana. Item 'lokasi yang sesuai' mencatat nilai min yang paling tinggi $\mathrm{M}=3.462$, dengan $42.5 \%$ responden setuju dengan pernyataan tersebut. Bagi item 'papan tanda arah adalah jelas' pula mencatat nilai min yang kedua tertinggi $\mathrm{M}=3.441$ dengan $41.0 \%$ responden setuju dengan pernyataan tersebut. Item 'papan tanda arah selalu dikemaskini' mencatatkan skor min yang paling rendah $\mathrm{M}=2.889$, dengan hanya $36.6 \%$ responden yang menyatakan agak bersetuju dengan kenyataan tersebut (Jadual 1).

Jadual 1. Papan tanda arah

\begin{tabular}{|c|c|c|c|c|c|c|}
\hline \multirow[b]{2}{*}{ Item } & \multirow[b]{2}{*}{ Min } & \multicolumn{5}{|c|}{ Kekerapan (peratusan) } \\
\hline & & $\begin{array}{l}\text { Sangat tidak } \\
\text { setuju }\end{array}$ & $\begin{array}{l}\text { Tidak } \\
\text { setuju }\end{array}$ & $\begin{array}{l}\text { Agak } \\
\text { setuju }\end{array}$ & Setuju & $\begin{array}{l}\text { Sangat } \\
\text { setuju }\end{array}$ \\
\hline Lokasi yang sesuai & 3.462 & $22(1.6)$ & $174(12.7)$ & $459(33.4)$ & $584(42.5)$ & $134(9.8)$ \\
\hline Papan tanda arah adalah jelas & 3.441 & $27(2.0)$ & $214(15.6)$ & $414(30.2)$ & $563(41.0)$ & $155(11.3)$ \\
\hline $\begin{array}{l}\text { Papan tanda arah amat membantu } \\
\text { untuk ke lokasi yang ingin dituju }\end{array}$ & 3.411 & $30(2.2)$ & $201(14.6)$ & $460(33.5)$ & $539(39.3)$ & $143(10.4)$ \\
\hline Papan tanda arah tidak mengelirukan & 3.405 & $23(1.7)$ & $218(15.9)$ & $436(31.8)$ & $571(41.6)$ & $125(9.1)$ \\
\hline $\begin{array}{l}\text { Bilangan papan tanda arah adalah } \\
\text { mencukupi }\end{array}$ & 3.126 & $63(4.6)$ & $314(22.9)$ & $475(34.6)$ & $429(31.2)$ & $92(6.7)$ \\
\hline Papan tanda arah selalu dikemaskini & 2.889 & $105(7.6)$ & $394(28.7)$ & $502(36.6)$ & $293(21.3)$ & $79(5.8)$ \\
\hline
\end{tabular}

Bagi aspek pengurusan papan tanda, responden berpendapat bahawa papan tanda arah perlu dikemaskini dan perlu ditambah, selari dengan perubahan ruang pejabat yang berlaku di dalam kampus. Hal ini membantu pengguna untuk menjimatkan masa dan dapat melaksanakan aktiviti dalam kampus dengan lebih lancar. Sebagai sebuah universiti yang sentiasa dikunjungi oleh pelawat dari luar, papan tanda arah yang dikemaskini dan mencukupi akan memudahkan pelawat dari luar sampai ke tempat yang ingin dituju. Pemilihan lokasi untuk pemasangan papan tanda arah juga memainkan peranan penting. Seringkali, papan tanda terlindung akibat dahan pokok yang semakin membesar dan menyukarkan pengguna melihat dan membaca arahan yang dinyatakan. Hal ini berkaitrapat dengan aspek penyelenggaraan yang merupakan antara faktor utama dalam mempengaruhi keberkesanan papan tanda arah yang disediakan, sebagaimana yang dinyatakan oleh Sahrir et al. (2012). 
Antara cadangan penambahbaikan yang dinyatakan oleh responden bagi aspek papan tanda arah ialah tentang penggunaan font yang besar dan jelas yang memudahkan pembacaan. Di samping itu, setiap papan tanda juga perlu disediakan dalam dua bahasa, Melayu dan Inggeris. Penggunaan kedua-dua bahasa ini perlu disemak oleh pakar bahasa untuk memastikan ketepatan perkataan yang digunakan. Penggunaan papan tanda pelbagai bahasa ini membantu menyelesaikan kesulitan yang dihadapai oleh pelajar antarabangsa, terutama pelajar baharu dalam urusan harian di kampus sebagaimana yang dinyatakan oleh Mahmud et al. (2010).

\section{Persepsi pengguna terhadap aliran trafik}

Bagi item dalam domain aliran trafik, nilai min menunjukkan responden mempunyai persepsi yang sederhana untuk kesemua item. Pernyataan 'aliran trafik diurus dengan baik' mencatatkan skor min yang paling tinggi $\mathrm{M}=3.533$. Pernyataan 'pemandu kenderaan luar yang menggunakan laluan dalam kampus sebagai jalan pintas tidak menganggu aliran trafik' mencatatkan nilai skor min yang paling rendah $\mathrm{M}=2.835$ dengan $40.4 \%$ responden tidak bersetuju dengan pernyataan ini (Jadual 2).

Jadual 2. Aliran trafik

\begin{tabular}{|c|c|c|c|c|c|c|}
\hline \multirow[b]{2}{*}{ Item } & \multirow[b]{2}{*}{ Min } & \multicolumn{5}{|c|}{ Kekerapan (Peratusan) } \\
\hline & & $\begin{array}{c}\text { Sangat } \\
\text { tidak setuju }\end{array}$ & $\begin{array}{l}\text { Tidak } \\
\text { setuju }\end{array}$ & $\begin{array}{l}\text { Agak } \\
\text { setuju }\end{array}$ & Setuju & $\begin{array}{l}\text { Sangat } \\
\text { setuju }\end{array}$ \\
\hline Aliran trafik diurus dengan baik & 3.533 & $20(1.5)$ & $144(10.5)$ & $457(33.3)$ & $588(42.8)$ & $164(11.9)$ \\
\hline $\begin{array}{l}\text { Laluan khas sikal (laluan basikal) } \\
\text { tidak menyulitkan perjalanan }\end{array}$ & 3.506 & $87(6.3)$ & $139(10.1)$ & $355(25.9)$ & $576(42.0)$ & $216(15.7)$ \\
\hline $\begin{array}{l}\text { Aliran trafik tidak menjejaskan } \\
\text { kehadiran ke pejabat dan dewan } \\
\text { kuliah }\end{array}$ & 3.345 & $62(4.5)$ & $231(16.8)$ & $404(29.4)$ & $523(38.1)$ & $153(11.1)$ \\
\hline $\begin{array}{l}\text { Aliran trafik dalam kampus pada } \\
\text { waktu puncak lancar }\end{array}$ & 3.098 & $91(6.6)$ & 325 (23.) & $430(31.3)$ & $413(30.1)$ & $114(8.3)$ \\
\hline $\begin{array}{l}\text { Pertambahan kenderaan pengguna } \\
\text { tidak menganggu aliran trafik }\end{array}$ & 2.887 & $160(11.7)$ & $389(28.3)$ & $382(27.8)$ & $329(24.0)$ & $113(8.2)$ \\
\hline $\begin{array}{l}\text { Pemandu kenderaan luar yang } \\
\text { menggunakan laluan dalam } \\
\text { kampus sebagai jalan pintas tidak } \\
\text { menganggu aliran trafik }\end{array}$ & 2.835 & $202(14.7)$ & $353(25.7)$ & $382(27.8)$ & $341(24.8)$ & $95(6.9)$ \\
\hline
\end{tabular}

Responden kajian berpendapat kenderaan dari luar yang menggunakan laluan dalam kampus UPM sebagai jalan pintas menambahkan bilangan kenderaan dan membuatkan aliran trafik sesak, terutama pada waktu puncak. Hal ini boleh terjadi akibat daripada pengguna yang ingin mengelak dari menggunakan jalan yang diubahsuai akibat perlaksanaan projek pembangunan yang sedang rancak berhampiran kampus. Di samping itu, kedudukan kampus yang terletak bersebelahan dengan institusi kerajaan yang lain menambahkan bilangan kenderaan keluar masuk, terutama jika terdapat majlis rasmi atau program yang dilaksanakan dalam skala yang besar. Sehubungan itu, kebarangkalian pengguna untuk menggunakan laluan dalam kampus sebagai jalan pintas adalah tinggi dan memberi kesan kepada aliran trafik dalam kampus.

Kesesakan aliran trafik di dalam kampus universiti akibat pertambahan kenderaan boleh diatasi dengan menggalakkan penggunaan basikal, terutama pelajar, untuk ke kuliah. Jika sebelum ini, kebanyakan penggunaan basikal di dalam kampus adalah untuk tujuan riadah 
(Harifah et al., 2018), kini pelajar perlu digalakkan untuk berbasikal ke kuliah. Bagi mencapai tujuan ini, keselamatan laluan basikal perlu ditingkatkan dan perkhidmatan seperti bengkel membaiki basikal dan parkir yang sesuai amat diperlukan (Yuan et al., 2017). Di samping itu, kesesakan aliran trafik ini juga boleh diatasi dengan perkongsian kenderaan, sebagaimana yang dicadangkan oleh Roshahdeh dan Puan (2009).

\section{Persepsi pengguna terhadap operasi pintu pagar}

Bagi domain operasi pintu pagar, terdapat tiga item yang mempunyai nilai skor min pada tahap tinggi. Hal ini menunjukkan persepsi pengguna terhadap operasi pintu pagar dalam kampus adalah baik. Item 'penjadualan sesetengah pintu pagar secara berkala menjamin keselamatan warga kampus' dan item 'semua laluan pintu masuk dikawalselia oleh pengawal keselamatan' mencatatkan nilai skor min yang tinggi, $\mathrm{M}=3.775$ dan $\mathrm{M}=3.768$, dengan majoriti responden bersetuju dengan pernyataan ini (Jadual 3). Operasi pintu pagar juga antara perkara penting dalam memastikan sistem perkhidmatan pengangkutan di kampus UPM berjalan lancar. Responden bersetuju dengan amalan penjadualan pintu pagar secara berkala yang dapat menjamin keselamatan warga kampus. Pemeriksaan oleh pengawal keselamatan di setiap pintu masuk adalah salah satu cara untuk mengawal jumlah kenderaan yang memasuki kampus, terutama pada waktu puncak. Walaupun langkah ini dilihat akan menambahkan masa perjalanan, cara ini adalah berkesan untuk memantau kenderaan bukan milik pelajar dan staf, di samping mengesan penyalahgunaan pelekat kenderaan.

Jadual 3. Operasi pintu pagar

\begin{tabular}{|c|c|c|c|c|c|c|}
\hline \multirow[b]{2}{*}{ Item } & \multirow[b]{2}{*}{ Min } & \multicolumn{5}{|c|}{ Kekerapan (Peratusan) } \\
\hline & & $\begin{array}{c}\text { Sangat } \\
\text { tidak setuju }\end{array}$ & $\begin{array}{l}\text { Tidak } \\
\text { setuju }\end{array}$ & $\begin{array}{l}\text { Agak } \\
\text { setuju }\end{array}$ & Setuju & $\begin{array}{l}\text { Sangat } \\
\text { setuju }\end{array}$ \\
\hline $\begin{array}{l}\text { Penjadualan secara berkala menjamin } \\
\text { keselamatan }\end{array}$ & 3.777 & $24(1.7)$ & $103(7.5)$ & $293(21.3)$ & $691(50.3)$ & $262(19.1)$ \\
\hline Pengawalan oleh pengawal keselamatan & 3.768 & $21(1.5)$ & $116(8.4)$ & $303(22.1)$ & $653(47.6)$ & $280(20.4)$ \\
\hline $\begin{array}{l}\text { Bilangan pengawal keselamatan } \\
\text { mencukupi }\end{array}$ & 3.761 & $17(1.2)$ & $88(6.4)$ & $364(26.5)$ & $641(46.7)$ & $263(19.2)$ \\
\hline Ikut jadual yang ditetapkan & 3.640 & $46(3.4)$ & $127(9.2)$ & $346(25.2)$ & $610(44.4)$ & $244(17.8)$ \\
\hline $\begin{array}{l}\text { Pemeriksaan pelekat kenderaan di } \\
\text { semua pintu masuk }\end{array}$ & 3.518 & $41(3.0)$ & $193(14.1)$ & $383(27.9)$ & $526(38.3)$ & $230(16.8)$ \\
\hline
\end{tabular}

\section{Sikap pengguna jalanraya}

Bagi domain sikap pengguna, semua item menunjukkan nilai skor min pada tahap sederhana. Item 'pengguna akur dan peka dengan arahan pengawal lalu lintas' menunjukkan nilai skor min yang paling tinggi $\mathrm{M}=3.643$, dengan hanya $7.9 \%$ responden menyatakan tidak bersetuju dengan pernyataan tersebut (Jadual 4). Bagi melancarkan perjalanan kenderaan di dalam kampus sewaktu majlis rasmi universiti sedang berlangsung, pihak berwajib perlu melaksanakan sedikit pengubahsuaian terhadap laluan keluar masuk kenderaan dan ruang parkir. Dalam situasi ini, pengguna perlu peka dengan arahan pengawal lalu lintas dan mengamalkan sikap pemanduan yang baik.

Item 'pengguna tidak menyalahgunakan keistimewaan yang diberikan' mempunyai nilai min $\mathrm{M}=3.375$ menunjukkan responden memahami peraturan penggunaan perkhidmatan 
pengangkutan yang telah ditetapkan oleh pihak pengurusan university (Jadual 4). Sebagai contoh, pelekat kenderaan yang dikeluarkan oleh pihak berkenaan tidak disalahguna untuk tujuan tertentu. Di samping itu, responden berpendapat bahawa sikap pemandu kenderaan juga mempengaruhi kelancaran aliran trafik. Sebagaimana yang dinyatakan oleh Balsas (2003), kepelbagaian latar belakang ahli komuniti dalam kampus universiti turut mewujudkan perbezaan sikap dan ini termasuk juga tingkah laku apabila berada di jalanraya dan menggunakan pekhidmatan pengangkutan. Pematuhan kepada peraturan lalu lintas seperti had laju, lampu isyarat dan papan tanda arah adalah amat penting dalam memastikan keselamatan pengguna.

Jadual 4. Sikap pengguna jalanraya

\begin{tabular}{|c|c|c|c|c|c|c|}
\hline \multirow[b]{2}{*}{ Item } & \multirow[b]{2}{*}{ Min } & \multicolumn{5}{|c|}{ Kekerapan (Peratusan) } \\
\hline & & $\begin{array}{c}\text { Sangat } \\
\text { tidak } \\
\text { setuju }\end{array}$ & $\begin{array}{l}\text { Tidak } \\
\text { setuju }\end{array}$ & $\begin{array}{l}\text { Agak } \\
\text { setuju }\end{array}$ & Setuju & $\begin{array}{l}\text { Sangat } \\
\text { setuju }\end{array}$ \\
\hline Peka dengan arahan lalu lintas & 3.643 & $12(0.9)$ & $96(7.0)$ & $443(32.3)$ & $641(46.7)$ & $181(13.2)$ \\
\hline $\begin{array}{l}\text { Pengguna tidak menyalahgunakan } \\
\text { keistimewaan yang diberikan }\end{array}$ & 3.375 & $53(3.9)$ & $204(14.9)$ & $439(32.0)$ & $529(38.5)$ & $148(10.8)$ \\
\hline Akur pada peraturan lalu lintas & 3.263 & $45(3.3)$ & $246(17.9)$ & $493(35.9)$ & $481(35.0)$ & $108(7.9)$ \\
\hline $\begin{array}{l}\text { Masalah lalu lintas bukan disebabkan } \\
\text { oleh sikap pengguna }\end{array}$ & 3.014 & $99(7.2)$ & $365(26.6)$ & $436(31.8)$ & $364(26.5)$ & $109(7.9)$ \\
\hline
\end{tabular}

\section{Persepsi pemegang taruh terhadap parkir}

Item 'parkir bertingkat dapat membantu menyelesaikan masalah kekurangan parkir terutamanya pada majlis utama universiti' mempunyai skor min yang tinggi $\mathrm{M}=4.042$ dan majoriti responden bersetuju dengan pernyataan ini $(92.8 \%)$. Item yang mempunyai nilai skor min yang terendah pula ialah 'kemudahan parkir untuk pelajar, kakitangan dan pelawat adalah mencukupi', $\mathrm{M}=2.434$ (Jadual 5).

Jadual 5. Persepsi pemegang taruh terhadap parkir

\begin{tabular}{|c|c|c|c|c|c|c|}
\hline \multirow[b]{2}{*}{ Item } & \multirow[b]{2}{*}{ Min } & \multicolumn{5}{|c|}{ Kekerapan (Peratusan) } \\
\hline & & $\begin{array}{l}\text { Sangat } \\
\text { Tidak } \\
\text { Setuju }\end{array}$ & $\begin{array}{l}\text { Tidak } \\
\text { Setuju }\end{array}$ & $\begin{array}{l}\text { Agak } \\
\text { Setuju }\end{array}$ & Setuju & $\begin{array}{l}\text { Sangat } \\
\text { Setuju }\end{array}$ \\
\hline Penyediaan parkir bertingkat & 4.042 & $26(1.9 \%)$ & $72(5.2 \%)$ & $267(19.4 \%)$ & $461(33.6 \%)$ & $547(39.8 \%)$ \\
\hline Perlaksanaan Green Car Parking & 3.314 & $98(7.1 \%)$ & $200(14.6 \%)$ & $451(32.8 \%)$ & $421(30.7 \%)$ & $203(14.8 \%)$ \\
\hline $\begin{array}{l}\text { Ruang parkir adalah berdekatan dengan } \\
\text { pejabat/dewan kuliah/pusat aktiviti } \\
\text { mahasiswa (dewan, kafe, perpustakaan) }\end{array}$ & 3.237 & $108(7.9 \%)$ & $177(12.9 \%)$ & $487(35.5 \%)$ & $483(35.2 \%)$ & $118(8.6 \%)$ \\
\hline $\begin{array}{l}\text { Denda yang dikenakan bagi adalah } \\
\text { berpatutan }\end{array}$ & 3.182 & $176(12.8 \%)$ & $201(14.6 \%)$ & $399(29.1 \%)$ & $393(28.6 \%)$ & $204(14.9 \%)$ \\
\hline $\begin{array}{l}\text { Parkir yang disediakan untuk golongan } \\
\text { OKU tidak disalahgunakan }\end{array}$ & 3.149 & $98(7.1 \%)$ & $226(16.5 \%)$ & $548(39.9 \%)$ & $376(27.4 \%)$ & $125(9.1 \%)$ \\
\hline $\begin{array}{l}\text { Penandaan tempat parkir jelas untuk } \\
\text { kategori pengguna }\end{array}$ & 3.026 & $134(9.8 \%)$ & $306(22.3 \%)$ & $425(31.0 \%)$ & $406(29.6 \%)$ & $102(7.4 \%)$ \\
\hline $\begin{array}{l}\text { Kemudahan parkir untuk pelajar, } \\
\text { kakitangan dan pelawat adalah } \\
\text { mencukupi }\end{array}$ & 2.434 & $360(26.2 \%)$ & $420(30.6 \%)$ & $292(21.3 \%)$ & $239(17.4 \%)$ & $62(4.5 \%)$ \\
\hline
\end{tabular}


Responden berpandangan pembinaan parkir bertingkat dapat membantu menyelesaikan masalah kekurangan parkir di dalam kampus, terutama ketika majlis dan aktiviti utama universiti seperti Majlis konvokesyen dan pendaftaran pelajar baharu. Selain itu, kemudahan parkir untuk pelajar, kakitangan dan pelawat juga adalah tidak mencukupi dan ini akan menyebabkan perebutan parkir antara pelajar, staf dan pelawat. Sebagai contoh, pelajar yang lambat untuk menghadiri kelas atau peperiksaan cenderung untuk meletakkan kenderaan di tempat yang tidak sepatutnya untuk menjimatkan masa. Parkir yang digunakan kemungkinan parkir untuk staf dan mungkin juga parkir untuk orang kurang upaya. Walau bagaimanapun, Riggs (2014) menyatakan bahawa sesebuah kampus perlu mengimbangi kecukupan lot tempat letak kenderaan dengan kekangan tanah, di samping perlu mengambilkira kos yang tinggi dan boleh menyebabkan kemusnahan alam sekitar.

\section{Persepsi pelajar terhadap perkhidmatan bas}

Bagi domain perkhidmatan bas, analisis dilaksanakan terhadap 1039 (75.7\%) orang responden kajian yang pernah menggunakan perkhidmatan bas dalam tempoh setahun yang lalu. Hasil analisis mendapati terdapat dua item yang menunjukkan nilai skor min yang berada pada tahap tinggi, iaitu item 'bas yang digunakan adalah berhawa dingin, bersih dan selesa' $\mathrm{M}=3.911$ dan item 'pelajar mematuhi arahan keselamatan dan kebersihan ketika menggunakan perkhidmatan bas', $M=3.653$. Manakala dua item yang menunjukkan nilai skor min yang terendah tapi masih pada tahap sederhana ialah item 'secara keseluruhannya, perkhidmatan bas di UPM adalah memuaskan' $\mathrm{M}=3.173$, dan item 'pemandu bas mematuhi jadual perjalanan yang disediakan oleh pihak UPM' juga mencatatkan skor yang rendah M=3.195 (Jadual 6).

Jadual 6. Perkhidmatan bas

\begin{tabular}{|c|c|c|c|c|c|c|}
\hline \multirow[b]{2}{*}{ Item } & \multirow[b]{2}{*}{ Min } & \multicolumn{5}{|c|}{ Kekerapan (Peratusan) } \\
\hline & & $\begin{array}{c}\text { Sangat } \\
\text { tidak setuju }\end{array}$ & $\begin{array}{l}\text { Tidak } \\
\text { setuju }\end{array}$ & $\begin{array}{l}\text { Agak } \\
\text { setuju }\end{array}$ & Setuju & $\begin{array}{l}\text { Sangat } \\
\text { setuju }\end{array}$ \\
\hline $\begin{array}{l}\text { Bas adalah berhawa dingin, bersih dan } \\
\text { selesa. }\end{array}$ & 3.911 & $9(1.0)$ & $43(4.1)$ & $270(25.9)$ & $427(41.1 \%)$ & $290(27.9)$ \\
\hline $\begin{array}{l}\text { Pengguna mematuhi arahan keselamatan } \\
\text { dan kebersihan. }\end{array}$ & 3.654 & $25(2.4)$ & $81(7.8 \%)$ & $316(30.4)$ & $424(40.8)$ & $193(18.6)$ \\
\hline $\begin{array}{l}\text { Pemandu bas bertimbang rasa terhadap } \\
\text { pengguna jalan raya yang lain. }\end{array}$ & 3.447 & $43(4.1)$ & $100(9.6)$ & $366(35.2)$ & $410(39.5)$ & $120(11.5)$ \\
\hline $\begin{array}{l}\text { Pemandu bas mematuhi arahan lalu } \\
\text { lintas }\end{array}$ & 3.372 & $54(5.2)$ & $126(12.1)$ & $359(34.6)$ & $380(36.5)$ & $120(11.5)$ \\
\hline $\begin{array}{l}\text { Sebarang aduan tentang perkhidmatan } \\
\text { bas di UPM dikendalikan dengan baik. }\end{array}$ & 3.334 & $68(6.5)$ & $121(11.6)$ & $380(36.6)$ & $336(32.3)$ & $134(12.9)$ \\
\hline Tambang adalah berpatutan. & 3.331 & $75(7.2)$ & $100(9.6)$ & $407(39.2)$ & $320(30.7)$ & 137(13.2) \\
\hline Hentian bas yang selesa & 3.257 & $83(7.9)$ & $136(13.1)$ & $371(35.8)$ & $329(31.7)$ & $120(11.5)$ \\
\hline $\begin{array}{l}\text { Pemandu bas mematuhi jadual } \\
\text { perjalanan }\end{array}$ & 3.195 & $80(7.7)$ & $177(17.0)$ & $334(32.1)$ & $356(34.3)$ & $92(8.9)$ \\
\hline Perkhidmatan bas adalah memuaskan & 3.173 & $87(8.3)$ & $173(16.7)$ & 354 (34.) & $323(31.1)$ & $102(9.8)$ \\
\hline
\end{tabular}

Bagi aspek perkhidmatan bas, responden yang terdiri daripada pelajar prasiswazah dan pasca siswazah berpendapat walaupun bas yang digunakan adalah berhawa dingin, bersih dan selesa, secara keseluruhannya perkhidmatan bas dalam kampus adalah kurang memuaskan, terutamanya dari segi pematuhan jadual perjalanan. Perkhidmatan bas yang kurang memuaskan akan memberi kesan negatif kepada para pelajar, seperti gagal hadir ke kelas atau aktiviti universiti yang lain 
(Hashim et al., 2013). Secara tidak langsung, meningkatkan kemahuan pelajar untuk memiliki kenderaan seperti motorsikal atau kereta. Pertambahan bilangan kenderaan juga memberi kesan yang tidak baik ke atas alam sekitar. Oleh itu, pihak universiti perlu menggalakkan penggunaan perkhidmatan bas yang disediakan dengan sentiasa menambahbaik perkhidmatan yang sedia ada selaras dengan perkembangan semasa.

Bagi item 'hentian bas adalah selesa',79.0\% responden menyatakan persetujuan terhadap pernyataan ini, sebagaimana dapatan oleh Shaaban dan Kim, (2016). Selain itu, responden mencadangkan agar jumlah perjalanan bas ditambah bagi membantu pelajar menjimatkan masa menunggu. Ini disokong dapatan kajian oleh Azani et al. (2017). Penggunaan teknologi terkini juga perlu dimanfaatkan oleh pihak universiti untuk meningkatkan kecekapan sistem perkhidmatan pengangkutan. Sebagai contoh, satu aplikasi mobil dicipta untuk membolehkan pengguna, khususnya pelajar melihat perjalanan bas dari satu destinasi ke satu destinasi dan ini amat membantu pelajar merancang perjalanan seterusnya menjimatkan masa.

\section{Kesimpulan}

Secara keseluruhannya, pemegang taruh mempunyai persepsi yang positif terhadap sistem perkhidmatan pengangkutan di kampus UPM, Serdang. Pemegang taruh juga berpuas hati dengan sistem perkhidmatan pengangkutan, namun penambahbaikan masih perlu dilaksanakan selaras dengan misi dan matlamat universiti. Penambahbaikan yang dilaksanakan perlu mengambil kira kos yang efektif dan tidak membebankan universiti. Aspek penyelenggaraan adalah amat penting dalam memastikan infrastruktur yang dibina dapat digunakan dengan sebaik mungkin. Selain jalan raya, papan tanda arah dan laluan basikal juga perlu diselenggara secara berkala dalam memastikan fungsinya tidak terjejas. Sistem perkhidmatan pengangkutan di kampus yang efisyen akan memberi kesan positif kepada pencapaian universiti secara keseluruhan. Implikasinya, sesebuah kampus universiti yang lestari memerlukan sistem perkhidmatan pengangkutan di kampus yang cekap dan tidak menjejaskan alam sekitar dengan menggalakkan aktiviti berbasikal dan berjalan kaki. Aktiviti sihat ini akan dapat dilaksanakan dengan berkesan sekiranya pelajar dan staf sedar tentang kepentingan amalan gaya hidup sihat, di samping sokongan infrastruktur yang sesuai. Hal ini akan memberi kesan positif kepada pencapaian universiti secara keseluruhan dan menghasilkan komuniti universiti yang produktif.

Aspek yang menjadi keutamaan ialah kecekapan sistem perkhidmatan pengangkutan membantu pelajar mengurus masa, seterusnya membantu proses pembelajaran dan meningkatkan penglibatan dalam pelbagai aktiviti anjuran universiti. Bagi staf pula, perkara ini akan menimbulkan rasa gembira untuk melaksanakan tugas dan dapat menghasilkan output yang kreatif dan inovatif. Penggunaan teknologi terkini boleh dimanfaatkan untuk mencipta pelbagai aplikasi dan sistem navigasi untuk memudahkan pelajar, staf mahupun pelawat bergerak dalam kampus, dan menyelesaikan segala urusan dengan cepat.

\section{Penghargaan}

Kajian ini dibiayai oleh Geran Penyelidikan Putra GP-IPM/1/2016/9508000 Universiti Putra Malaysia. 


\section{Rujukan}

Asnarulkhadi, A.S., Siti Zobidah O., Khairuddin, I., Dahlia, Z., Nor Wahiza, A.W., Jeffrey Lawrence, D.S., \& Nurul Akhtar, K. (2018). Laporan Kajian Indeks Kegembiraan UPM Fasa 2, 2017. Institut Pengajian Sains Sosial, Universiti Putra Malaysia.

Azani Azreen Alia Natasy Abu Bakar, Noor Shuhada Abd Rahman, Siti Zulaikah, Tengku Jesceedza, Tengku Nur Syazleedza Edzry, \& Radzuan Kamaruddin. (2017). Students' satisfaction towards bus service performance. Symposium on Technology Management \& Logistics (STML-Go Green) 2016. 6-7 December. Universiti Utara Malaysia, Sintok, Malaysia.

Balsas, C.J. (2003). Sustainable transportation planning on college campusses. Transport Policy, 10(1), 35-49.

Field, T., Diego, M., \& Sanders, C.E. (2001). Exercise is positively related to adolescents' relationships and academics. Adolescence, 36(141), 105-105.

Harifah Mohd Noor, Marja Azlima, \& Rosmiza M.Z. (2018). Aktiviti berbasikal: Pemangkin kelestarian kampus. Geografia: Malaysian Journal of Society and Space, 14(3), 85-100.

Hashim, R., Haron, S., Mohamad, S., \& Hassan, F. (2013). Assessment of campus bus service efficacy: An application towards green environment. Procedia-Social and Behavioral Sciences, 105, 294-303.

Juarez, B. (2011). Best practices for university bus transit programs: Identifying strategies for success (Master dissertation). Retrieved from Texas State University-San Marcos.

Kaplan, D.H. (2015). Transportation sustainability on a university campus. International Journal of Sustainability in Higher Education, 16(2), 173-186.

Klöckner, C.A., \& Friedrichsmeier, T. (2011). A multi-level approach to travel mode choiceHow person characteristics and situation specific aspects determine car use in a student sample. Transportation Research Part F: Traffic Psychology and Behaviour, 14(4), 261277.

Limanond, T., Butsingkorn, T., \& Chermkhunthod, C. (2011). Travel behavior of university students who live on campus: A case study of a rural university in Asia. Transport Policy, 18(1), 163-171.

Mahmud, Z., Amat, S., Rahman, S., \& Ishak, N.M. (2010). Challenges for international students in Malaysia: Culture, climate and care. Procedia-Social and Behavioral Sciences, 7, 289293.

Mat, S., Sopian, K., Mokhtar, M., Ali, B., Hashim, H.S., Rashid, A.K.A., \& Ho, G.T. (2009). Managing sustainable campus in Malaysia-organisational approach and measures. European Journal of Social Sciences, 8(2), 201-214.

Miralles-Guasch, C., \& Domene, E. (2010). Sustainable transport challenges in a suburban university: The case of the Autonomous University of Barcelona. Transport Policy, 17(6), 454-463.

Mohd Majid Konting. (2000). Kaedah penyelidikan pendidikan. Kuala Lumpur, Dewan Bahasa dan Pustaka.

Nursyuhadah Norzalwi \& Amirussin Ismail. (2011). Public approach towards sustainable transportation in UKM's campus. Australian Journal of Basic and Applied Sciences, 5(5), 1332-1337.

Riggs, W. (2014). Dealing with parking issues on an urban campus: The case of UC Berkeley. Case Studies on Transport Policy, 2(3), 168-176. 
Roshandeh, A.M., \& Puan, O.C. (2009). Evaluation of University Technology Malaysia on campus transport access management. World Academy of Science, Engineering and Technology, International Journal of Social, Behavioral, Educational, Economic, Business and Industrial Engineering, 3(6), 814-819.

Sahrir, S., Bachok, S., \& Osman, M.M. (2012). The effectiveness of provision of new static information signage: A case study of International Islamic University Malaysia, Gombak Campus. Planning Malaysia Journal, 10(3), 228-243.

Shaaban, K., \& Kim, I. (2016). The influence of bus service satisfaction on university students' mode choice. Journal of Advanced Transportation, 50(6), 935-948.

Shannon, T., Giles-Corti, B., Pikora, T., Bulsara, M., Shilton, T., \& Bull, F. (2006). Active commuting in a university setting: Assessing commuting habits and potential for modal change. Transport Policy, 13(3), 240-253.

Toor, W. \& Havlick, S. (2004). Transportation and sustainable campus communities: Issues, examples, solutions. Washington, D.C., Island Press.

Whalen, K.E., Páez, A., \& Carrasco, J.A. (2013). Mode choice of university students commuting to school and the role of active travel. Journal of Transport Geography, 31, 132-142.

Yuan, C., Sun, Y., Lv, J., \& Lusk, A. (2017) Cycle tracks and parking environments in China: Learning from college students at Peking University. International Journal of Environmental Research and Public Health, 14(8), 930.

Zhou, J. (2012). Sustainable commute in a car-dominant city: Factors affecting alternative mode choices among university students. Transportation Research Part A: Policy and Practice, 46(7), 1013-1029. 